\title{
Variasi Konsentrasi Air Limbah Proses Pencucian Pulp pada Membraneless Air Cathode Microbial Fuel Cell
}

\author{
Krisna Adhitya Wardhana ${ }^{*}$, Agus Jatnika Effendi ${ }^{2}$ \\ ${ }^{1}$ Balai Besar Pulp dan Kertas, Jalan Raya Dayeuhkolot 132, Bandung \\ ${ }^{2}$ Institut Teknologi Bandung, Jalan Ganesha 10, Bandung
}

Diterima : 12 Juli 2019, Revisi akhir : 10 Desember 2019, Disetujui terbit : 30 Desember 2019

\section{The Concentration Variation of Wastewater from Pulp Washing Process in Membraneless Air Cathode Microbial Fuel Cell}

\begin{abstract}
A one compartment Membraneless-Microbial Fuel Cell (ML-MFC) with an air cathode was recently developed and became alternative solution for renewable energy sources to generate electricity from substrate degradation. MFC needs proper substrate that was rich in organic content such as wastewater from pulp washing process. The wastewater contains black liquor that was already diluted and contains lignin and high organic content, so that it would be potential as MFC substrate. Furthermore, the utilization of industrial wastewater as substrate can contribute positive effect to the environment namely contaminant reduction. This research was conducted to understand the effect of initial Chemical Oxygen Demand (COD) concentration of wastewater from pulp washing process to electricity current and voltage occured from MFC. The wastewater from pulp washing process with 4 initial COD concentrations $(61,833,940$, and $1620 \mathrm{mg} / \mathrm{L})$ and $\mathrm{pH}$ ranged from 8,91 to 10,03 were treated in a batch system using the MFC. The results showed that 34-48\% COD removal can be performed by MFC. Related with electricity potency from $M F C$, electricity accumulation current happened on 12,67 mA/m $\mathrm{m}^{2}-39,17 \mathrm{~mA} / \mathrm{m}^{2}$ at highest voltage from 4 reactors of 214-287 $\mathrm{mV}$.
\end{abstract}

Keywords: ML-MFC, air cathode, pulp washing process wastewater, electricity

\begin{abstract}
Abstrak
Membraneless-Microbial Fuel Cell (ML-MFC) satu kompartemen dengan katoda kontak udara saat ini sedang dikembangkan dan menjadi alternatif solusi untuk sumber energi terbarukan yang mampu menghasilkan listrik dari proses degradasi substrat. MFC membutuhkan substrat yang kaya senyawa organik seperti air limbah dari proses pencucian pulp. Pada air limbah ini terdapat lindi hitam dalam kondisi terencerkan yang mengandung lignin dan kaya senyawa organik sehingga memiliki potensi untuk digunakan sebagai substrat dalam reaktor MFC. Selain itu, penggunaan substrat berupa air limbah industri memiliki efek yang baik terhadap lingkungan karena berkontribusi dalam pengurangan kontaminan. Penelitian ini bertujuan untuk mengetahui pengaruh konsentrasi awal Chemical Oxygen Demand (COD) air limbah pencucian pulp sebagai substrat terhadap arus dan voltase listrik yang terjadi dalam MFC. Dalam penelitian ini, reaktor MFC mengolah air limbah pencucian secara batch dengan 4 variasi konsentrasi COD yaitu $613 \mathrm{mg} / \mathrm{L}, 833 \mathrm{mg} / \mathrm{L}, 940 \mathrm{mg} / \mathrm{L}$, dan $1620 \mathrm{mg} / \mathrm{L}$ dengan $\mathrm{pH}$ 8,91 - 10,03. Hasil penelitian menunjukkan MFC mampu mereduksi COD air limbah pencucian pulp sebesar 34 - 48\%. Terkait potensi listrik, akumulasi arus listrik yang terjadi pada MFC sebesar $12,67-39,17 \mathrm{~mA} / \mathrm{m}^{2}$ pada kisaran voltase tertinggi dari 4 reaktor sebesar 214 - $287 \mathrm{mV}$.
\end{abstract}

Kata kunci: ML-MFC, katoda kontak udara, air limbah pencucian pulp, listrik 


\section{Pendahuluan}

Microbial Fuel Cell (MFC) merupakan teknologi yang menggunakan mikroba anaerobik untuk mengkatalisis perubahan material organik dalam substrat menghasilkan elektron dan proton yang berpotensi dimanfaatkan sebagai sumber listrik. Dalam proses MFC, elektron yang dihasilkan bergerak keluar dari chamber anoda melalui external circuit dan proton berpindah menuju katoda dengan menyebar melalui larutan (Cheng, Liu and Logan, 2006). Selama kondisi ideal yang dibutuhkan dapat dipertahankan, MFC berpotensi menghasilkan listrik tanpa batas waktu. Aplikasi teknologi MFC memiliki beberapa hambatan, diantaranya konfigurasi awal MFC dengan 2 chamber sebagai chamber anoda dan katoda membuatnya jadi kurang ekonomis. Reaktor MFC single chamber yang lebih sederhana didesain dengan biaya yang lebih rendah dengan harapan agar lebih mudah diaplikasikan kedepannya (Thung et al., 2015). Reaktor MFC single chamber menggunakan air cathode untuk menggantikan keberadaan chamber anoda sehingga lebih efisien terkait tempat dan juga operasionalnya. Jenis MFC ini mengurangi kebutuhan energi, mengingat pada model 2 chamber memerlukan energi untuk proses aerasi pada chamber katoda sementara model 1 chamber tidak memerlukan itu karena katoda langsung dikontakkan dengan udara dengan pertimbangan bahwa keberadaan oksigen di udara lebih banyak dibandingkan di air sehingga peletakan karbon sebagai katoda yang kontak langsung dengan udara dirasa lebih baik dibandingkan dengan kondisi tercelup air. Hanya saja, jenis air cathode MFC ini memiliki kelemahan, yaitu dapat meningkatkan difusi oksigen pada anoda. Proses pada air cathode MFC terjadi berdasarkan adanya gradien Dissolved Oxygen (DO) antara bagian anaerob dan aerob dari reaktor MFC. Reaksi pada anoda sangat sensitif terhadap adanya oksigen terlarut karena dapat menghambat metabolisme mikroba anaerob dan juga menyebabkan terjadinya persaingan dengan anoda sebagai penerima elektron dalam rangka menggunakan elektron yang dihasilkan pada proses metabolisme. Oleh karena itu, desain yang tepat dari reaktor air cathode MFC dapat meminimalisasi difusi oksigen yang terjadi. Selain itu, adanya lapisan biofilm dapat membantu menghilangkan oksigen yang terdifusi dalam reaktor (Tanikkul and Pisutpaisal, 2015).
Kinerja dari MFC dapat dipengaruhi oleh aktivitas mikroba, jenis substrat, dan tipe dari proton exchange material (Tanikkul and Pisutpaisal, 2015). Dalam MFC dikenal adanya mikroba electrigens, yaitu mikroba yang dapat menyimpan energi untuk mendukung pertumbuhannya dengan mengoksidasi secara sempurna bahan organik menjadi karbon dioksida dengan transfer elektron langsung ke anoda MFC. Contohnya Geobacter sulfurreducens (Lovley and Nevin, 2008). Logan (2009) menyampaikan bahwa mikroorganisme memperoleh energi dari oksidasi substrat yang ada sehingga mengurangi energi yang seharusnya bisa dijadikan listrik. Dengan demikian, listrik yang dihasilkan dapat dipengaruhi oleh energi yang digunakan mikroba dan kehilangan energi pada katoda. Mikroorganisme yang bervariasi dapat ditemukan pada elektroda sistem MFC (Bond et al., 2002). Material elektroda juga mempengaruhi kinerja MFC. Material yang digunakan di kompartemen anoda harus bersifat diantaranya tidak korosif, tidak berefek negatif pada kehidupan mikroba, dan juga stabil. Karbon merupakan material yang banyak digunakan sebagai katoda dan anoda dalam MFC. Substrat juga merupakan faktor penting yang dapat mendukung proses konversi senyawa organik menjadi listrik yang melibatkan mikroba (biokonversi) dalam bioreaktor MFC. Penggunaan air limbah sebagai substrat akan menguntungkan karena selain mengurangi material pencemar dalam air limbah, penggunaan air limbah sebagai substrat dapat menghasilkan listrik sebagai sumber energi baru dan terbarukan. Lebih lanjut, Parkash et al. (2015) menambahkan bahwa air limbah domestik dan industri merupakan substrat yang mendukung terjadinya proses biokonversi dalam bioreaktor. Hal ini diperkuat Mahendra dan Mahavarkar (2013) yang menyebutkan bahwa MFC dapat digunakan untuk menghasilkan listrik dari proses pengolahan air limbah. Air limbah proses pembuatan pulp banyak mengandung senyawa organik yang berasal dari bahan bakunya (Doma and Abou-Elela, 2003). Air limbah ini disebut dengan lindi hitam yang memiliki konsentrasi COD berkisar antara 25-120 gr/L dan $\mathrm{pH}$ berkisar antara 9-14. Lindi hitam mengandung banyak material lignin yang terlepas dari bahan baku pada proses pemasakan. Selain itu, dalam lindi hitam juga terdapat serat dan bahan organik lain yang mengandung nilai 
COD, BOD (Biological Oxygen Demand) tinggi dan juga pencemar warna (Chen et al., 2016). Setelah dipisahkan dari lindi hitamnya, pulp hasil pemasakan mengalami proses washing yang disebut dengan brown stock washing. Chen et al. (2016) menyatakan bahwa proses pencucian terdiri dari 3 tahapan, dengan nilai COD dari masing-masing tahap akan semakin menurun dimana kisaran nilai COD pada pencucian tahap ketiga adalah $668-3306 \mathrm{mg} / \mathrm{L}$ dengan nilai $\mathrm{BOD}_{5}$ 180-391 $\mathrm{mg} / \mathrm{L}$. Proses pencucian pulp sangat dibutuhkan dan penting dalam keseluruhan proses karena mempengaruhi desain dan operasional proses bleaching serta terkait dengan dihasilkannya polutan organik yang toksik seperti Adsorbable Organic Halide (AOX) (Shukla et al., 2013). Berdasarkan potensi dan banyaknya kandungan senyawa organik, maka penelitian ini mencoba mengolah air limbah proses pencucian tahap akhir sisa lindi hitam dalam stock pulp dengan menggunakan air cathode MFC dengan tujuan meneliti potensi MFC dalam menurunkan konsentrasi COD air limbah pencucian pulp, dan mengukur voltase serta arus listrik pada reaktor MFC.

\section{Bahan dan Metode}

\section{Bahan}

Bahan utama yang digunakan dalam penelitian ini adalah air limbah simulasi pencucian pulp yang didapatkan dari pengenceran lindi hitam dengan demineralized water. Bahan lainnya adalah kultur mikroba yang berasal dari kultur yang diambil dari bak anaerobik yang biasa mengolah limbah cair domestik sehingga ketika digunakan untuk mengolah limbah industri diperlukan aklimatisasi terlebih dahulu. Peralatan utama yang diperlukan adalah reaktor MFC yang dibuat dari material PVC (Polyvinyl chloride) dan memiliki diameter 3 inci dengan tinggi $25 \mathrm{~cm}$ beserta kelengkapannya seperti batang karbon sebagai elektroda, water circulator dalam rangka untuk homogenisasi kondisi dalam larutan MFC, dan juga kabel sebagai pengalir elektron.

\section{Metode}

Konsentrasi awal COD air limbah simulasi pencucian divariasikan, yaitu berkisar pada konsentrasi COD $\pm 600 \mathrm{mg} / \mathrm{L}- \pm 1600 \mathrm{mg} / \mathrm{L}$ yang didapatkan dari pengenceran lindi hitam. Kisaran ini masih berada pada kisaran karakteristik teoritis air limbah pencucian tahap ketiga yang berada di kisaran nilai COD 668-3306 mg/L. Pengenceran ini merupakan salah satu teknik pencucian brown stock yang umum digunakan. Jumlah reaktor MFC berjumlah 4 reaktor pengolahan dan 1 reaktor sebagai kontrol yang berisi air limbah tanpa kultur mikroba di dalamnya. Reaktor kontrol digunakan untuk mengoreksi ion yang memang sudah ada dari air limbah dan bukan sebagai hasil aktivitas mikroba dalam proses pengolahan. Ion yang dikoreksi ini berada dalam air limbah pencucian karena adanya penambahan bahan kimia pada proses-proses sebelumnya, seperti penambahan $\mathrm{NaOH}$ pada proses pemasakan pulp. Keberadaan reaktor kontrol diperlukan karena berdasarkan pengukuran awal, pada air limbah awal sudah terhitung adanya tegangan / voltase yang menandakan adanya beda potensial yang disebabkan adanya elektron dan proton yang sudah terdapat pada air limbah tersebut sehingga untuk menghindari kesalahan persepsi digunakan reaktor kontrol karena diharapkan elektron dan proton yang dihasilkan dalam penelitian ini adalah hasil aktivitas mikroba.

Sistem MFC yang digunakan adalah air cathode single chamber. Anoda dan katoda yang digunakan adalah batang karbon dengan luas permukaan karbon untuk anoda berkisar $180 \quad-184 \quad \mathrm{~cm}^{2}$ dan katoda 37 - $44 \mathrm{~cm}^{2}$. Jumlah karbon disetiap reaktor adalah 2 untuk anoda dan 2 untuk katoda dengan jarak antara anoda dan katoda kurang lebih sekitar $13 \mathrm{~cm}$. Kekurangan air cathode terkait terjadinya difusi oksigen diminimalkan dengan menerapkan bentuk L pada reaktor MFC dalam rangka mencegah difusi oksigen lebih dalam ke dalam chamber anoda, menambahkan penutup kedap pada bagian atas chamber anoda untuk mencegah masuknya oksigen dari lingkungan, dan melakukan pengecekan DO secara teratur setiap hari untuk mengetahui kondisi dalam reaktor MFC. Penambahan water circulator dilakukan untuk proses homogenisasi sehingga kontak antara mikroba dengan substrat yang ada dalam air limbah bisa terjadi lebih merata. Selain itu water circulator/mixing juga membantu dalam mengarahkan elektron yang terbentuk agar mengalir ke anoda. Proton exchange system menggunakan perbedaan gradien DO yang terjadi dalam reaktor dimana proton, seperti ion $\mathrm{H}^{+}$akan bergerak menuju katoda dengan menyebar melalui larutan. Pengalir proton dan elektron dari dalam 

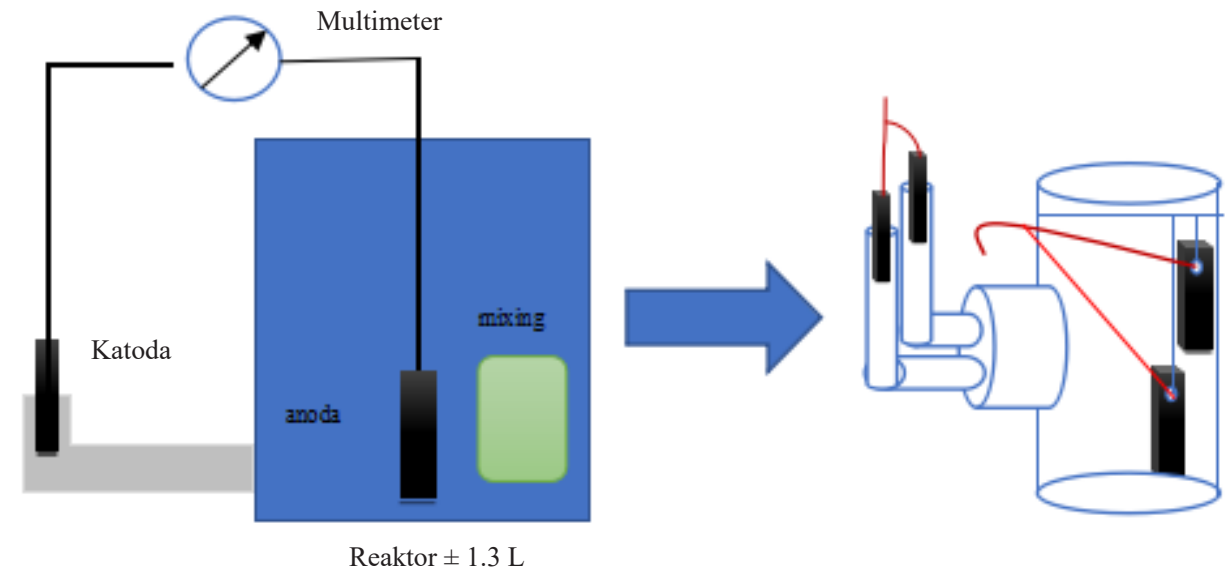

Reaktor $\pm 1.3 \mathrm{~L}$

Gambar 1. Reaktor MFC

elektroda supaya dapat dimanfaatkan dilakukan dengan menggunakan kabel. Reaktor MFC yang digunakan dapat dilihat pada Gambar 1.

Parameter proses yang diukur adalah penyisihan COD, tegangan listrik $(\mathrm{mV})$, dan arus listrik $\left(\mathrm{mA} / \mathrm{m}^{2}\right)$. Jumlah biomassa mikroba dalam reaktor diukur dengan melakukan pengecekan Mixed Liquor Suspended Solid (MLSS). Kondisi lingkungan yang mempengaruhi keefektifan proses seperti $\mathrm{DO}, \mathrm{pH}$, dan temperatur juga diukur. Konsentrasi DO dicek menggunakan DO meter untuk mendapatkan informasi jumlah oksigen terlarut dalam reaktor sesuai untuk pertumbuhan mikroba anaerob, sedangkan nilai $\mathrm{pH}$ diukur menggunakan $\mathrm{pH}$ meter untuk mempertahankan keefektifan proses dalam reaktor MFC. Tegangan dan arus listrik diukur dengan multimeter digital. Pengukuran COD dilakukan secara refluks tertutup menggunakan spektrofotometri, MLSS dan TSS dianalisa dengan menggunakan uji TSS secara gravimetri. Mikroba anerob yang dominan bekerja adalah mikroba elektrogenik yang optimal pada $\mathrm{pH}>8$. Untuk mempertahankan $\mathrm{pH}$ ditambahkan larutan penyangga $\mathrm{Na}_{2} \mathrm{HCO}_{3}$ Proses degradasi zat organik dalam reaktor MFC menghasilkan $\mathrm{CO}_{2}$ yang dapat menurunkan $\mathrm{pH}$ larutan. Nutrisi seperti urea $\left(\mathrm{NH}_{2}\right)_{2} \mathrm{CO}$, dan asam fosfat $\left(\mathrm{H}_{3} \mathrm{PO}_{4}\right)$ juga ditambahkan ke dalam reaktor MFC. Model first order digunakan dalam rangka menentukan kinetika penurunan substrat (COD) air limbah pencucian dalam reaktor MFC. Durai (2010) menyebutkan bahwa model first order memiliki nilai koefisien determinasi yang lebih baik dalam kinetika penurunan substrat air limbah penyamakan dibandingkan model diffusional dan singh dengan persamaan: $\frac{-d C_{s}}{\mathrm{dt}}=\mathrm{k}_{1} \mathrm{C}_{\mathrm{s}}$

Setelah dilakukan integrasi dan waktu pengolahan dalam penelitian ini dalam hari, maka didapatkan persamaan:

$\operatorname{Ln} \frac{\mathrm{C}_{s}}{C_{s o}}=-\mathrm{k}_{1} \mathrm{t}$

dengan:

$\mathrm{k}_{1}=$ Konstanta kinetik first order, hari $^{-1}$

$\mathrm{C}_{\mathrm{s}}=$ Konsentrasi substrat, $\mathrm{mg} / \mathrm{L}$

$\mathrm{C}_{\mathrm{so}}=$ Konsentrasi substrat awal, $\mathrm{mg} / \mathrm{L}$

$\mathrm{t}^{\mathrm{so}}=$ Waktu pengolahan, hari

Konstanta first order dihitung dari waktu dan $\ln \left(\mathrm{C}_{\mathrm{s}} / \mathrm{C}_{\mathrm{so}}\right)$ yang kemudian diplotkan pada sumbu $\mathrm{x}$ dan $\mathrm{y}$.

\section{Hasil dan Pembahasan}

Penurunan konsentrasi COD setelah pengolahan dapat dilihat pada Gambar 2 yang menunjukkan bahwa efisiensi penyisihan COD dari 4 reaktor MFC yang digunakan berkisar antara $34-48 \%$. Nilai ini tidak berbeda jauh dengan hasil penelitian (Zhuwei et al., 2008) yang menggunakan membraneless MFC untuk mengolah air limbah sintesis (komposisi antara lain $\mathrm{NaHCO}_{3}, \mathrm{KCl}, \mathrm{NH}_{4} \mathrm{CL}$ ) dengan konsentrasi COD $880 \mathrm{mg} / \mathrm{L}$ dan mendapatkan efisiensi penyisihan COD sebesar $34 \%$ pada feeding rate $16 \mathrm{~mL} / \mathrm{jam}$ dan meningkat menjadi $42 \%$ pada feeding rate $8 \mathrm{~mL} / \mathrm{jam}$. Dari hasil penelitian Zhuwei et al. (2008) tersebut terlihat bahwa 


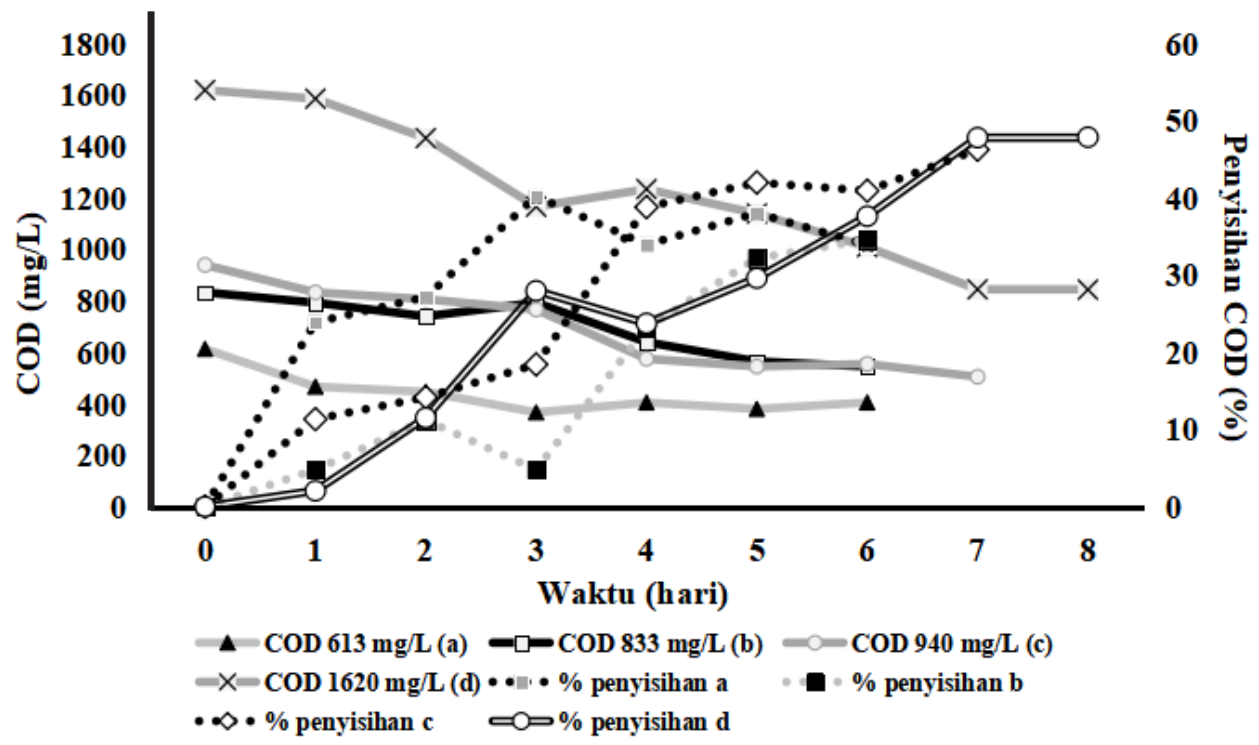

Gambar 2. Penurunan Konsentrasi dan Penyisihan COD Reaktor MFC

peningkatan feeding rate dalam reaktor MFC dapat menurunkan efisiensi penyisihan COD. Apabila dikaitkan dengan limbah industri pulp dan kertas, efisiensi penyisihan COD yang berkisar antara $34-48 \%$ ini tidak jauh berbeda dengan hasil penelitian yang telah dilakukan (Pramono et al., 2015) yang juga menggunakan membraneless MFC untuk mengolah air limbah industri pulp dan kertas terpadu dan menghasilkan efisiensi penyisihan COD sebesar 38,5\%.

Nilai efisiensi penyisihan COD yang dihasilkan dibawah 50\% dapat disebabkan terutama oleh dua hal, yaitu kondisi kompleksitas air limbah yang diolah dan gangguan terhadap kondisi proses reaktor MFC. Air limbah mengandung komponen lindi hitam yang merupakan senyawa organik komplek dengan rasio perbandingan $\mathrm{BOD} /$ COD mencapai 0,11 dan mengandung senyawa organik yang sulit dibiodegradasi oleh mikroba di dalam reaktor MFC. Adanya senyawa organik komplek yang bersifat tidak terbiodegradasi ini menyebabkan efisiensi penyisihan COD air limbah tidak mencapai $100 \%$. Hanya saja performa MFC menunjukkan hasil yang cukup positif dengan efisiensi $34-48 \%$. Nilai yang cukup menjanjikan mengingat kompleksitas air limbah yang digunakan. Efisiensi penyisihan COD tertinggi diperoleh reaktor 4 dengan efisiensi penyisihan COD 48\% pada konsentrasi COD awal tertinggi $(1620 \mathrm{mg} / \mathrm{L})$ dengan lamanya pengolahan di reaktor MFC (8 hari). Gambar 2 juga menunjukkan bahwa persentase penyisihan COD terbesar terjadi pada 4 hari pertama.
Dalam suatu pengolahan anaerob seperti MFC, selain proses degradasi substrat secara langsung, dapat juga terjadi proses hidrolisis yang mengonversi senyawa komplek dalam air limbah menjadi senyawa yang lebih sederhana sehingga dapat didegradasi pada pengolahan lanjutan setelah MFC, mengingat MFC sebagai pengolahan biologi anaerob bukan merupakan pengolahan akhir. Secara kualitatif, nilai COD tidak menurun drastis, namun adanya proses konversi senyawa komplek menjadi lebih sederhana memudahkan kinerja pengolahan selanjutnya dalam mendegradasi bahan pencemar yang masih tersisa. MFC merupakan jenis pengolahan anaerob dan seperti pengolahan anaerob lainnya, biasanya diteruskan dengan pengolahan aerob sebagai pengolahan lanjutan seperti lumpur aktif untuk mendegradasi senyawa pencemar yang masih ada.

Pertumbuhan biomassa di semua reaktor seperti pada Gambar 3 cenderung mengalami penurunan pada awal pengolahan dan kemudian mengalami peningkatan walaupun tidak signifikan pada hari berikutnya. Penurunan tersebut dapat disebabkan karena penyesuaian mikroba terhadap beban substrat yang diberikan. Selain itu, dapat dilihat bahwa puncak pertumbuhan biomassa dalam reaktor MFC umumnya terjadi pada rentang hari ke 4-6 dan kemudian menunjukkan penurunan seiring dengan berkurangnya substrat yang tersedia dalam reaktor. Jumlah MLSS terbesar terdapat pada reaktor dengan konsentrasi COD 1620 mg/L. Hal ini menunjukkan bahwa 
ketersediaan substrat mempengaruhi jumlah biomassa dalam reaktor. Semakin banyak substrat akan memberikan kesempatan bagi mikroba untuk berkembang lebih banyak, walaupun kemudian akan berkurang seiring dengan berkurangnya substrat. Pertumbuhan mikroba memiliki hubungan yang erat dengan efektivitas MFC karena pada dasarnya MFC adalah suatu pengolahan biologi anaerob dengan konfigurasi tertentu dalam rangka menghasilkan listrik. Dengan semakin banyaknya mikroba dalam sistem, diharapkan proses degradasi substrat organik dalam limbah cair yang terjadi dapat semakin besar dan cepat sehingga dihasilkan lebih banyak elektron dan proton yang bisa dikonversi menjadi listrik. Hanya saja seperti pengolahan biologi lainnya, diperlukan keseimbangan antara jumlah substrat dan mikroba dalam rangka efektivitas sistem utamanya dalam sistem aliran kontinyu. Jumlah mikroba yang terlalu banyak dapat tidak efektif terutama bila sistem aliran batch yang digunakan. Kompleksitas air limbah bisa menjadi penghambat pertumbuhan mikroba. Gambar 3 menunjukkan bahwa perkembangbiakan mikroba yang terjadi cenderung menurun. Franks dan Nevin (2010) menyebutkan bahwa dalam sistem MFC terjadi perkembangbiakan mikroba dengan jumlah yang lebih sedikit dibandingkan proses secara aerob. Lebih lanjut, Kim et al., (2008) menyebutkan bahwa elektron yang dihasilkan dari proses oksidasi substrat oleh mikroba dipindahkan ke anoda melalui 3 cara, yaitu transfer elektron secara langsung oleh mikroba yang menempel pada anoda, melalui nanowires yang dihasilkan mikroba tertentu dalam perpindahan jarak jauh, atau dengan menggunakan media yang berasal dari mikroba itu sendiri seperti exogenous mediator. Adanya sistem pemindahan elektron dengan menggunakan nanowires menandakan bahwa elektron yang digunakan untuk energi listrik tidak hanya berasal dari mikroba yang hidup melekat pada anoda. Dalam MFC sistem batch, keberadaan planktonic microbe yang tidak menempel juga berkontribusi dalammenghasilkan listrik selain dari attached microbe, hanya saja ketika sistem MFC yang digunakan kontinu, planktonic microbe tersebut dapat terbawa keluar karena adanya aliran, sehingga attached microbe yang lebih dominan. Zhuwei et al. (2008) menyebutkan bahwa $5 \%$ voltase keluaran MFC berasal dari kontribusi planktonic microbe dan 95\% dari attached microbe. Penelitian ini tidak mengkaji secara khusus jenis mikroba yang ada dalam reaktor MFC. Namun, penelitian ini mempertimbangkan sistem aliran batch yang digunakan dan visualisasi adanya lumpur mikroba di penjuru reaktor MFC termasuk adanya lapisan licin yang terbentuk pada anoda sehingga attached microbes dan planktonic microbe diperkirakan ada di dalam sistem. Penyisihan konsentrasi COD dalam air limbah pencucian dalam reaktor MFC yang dilakukan oleh kedua jenis mikroba tersebut jumlahnya dihitung sebagai nilai MLSS dan dapat dilihat pada Gambar 3.

Pola pertumbuhan mikroba dengan rentang waktu terlama (mencapai 5 hari) terdapat pada reaktor yang memiliki konsentrasi COD awal

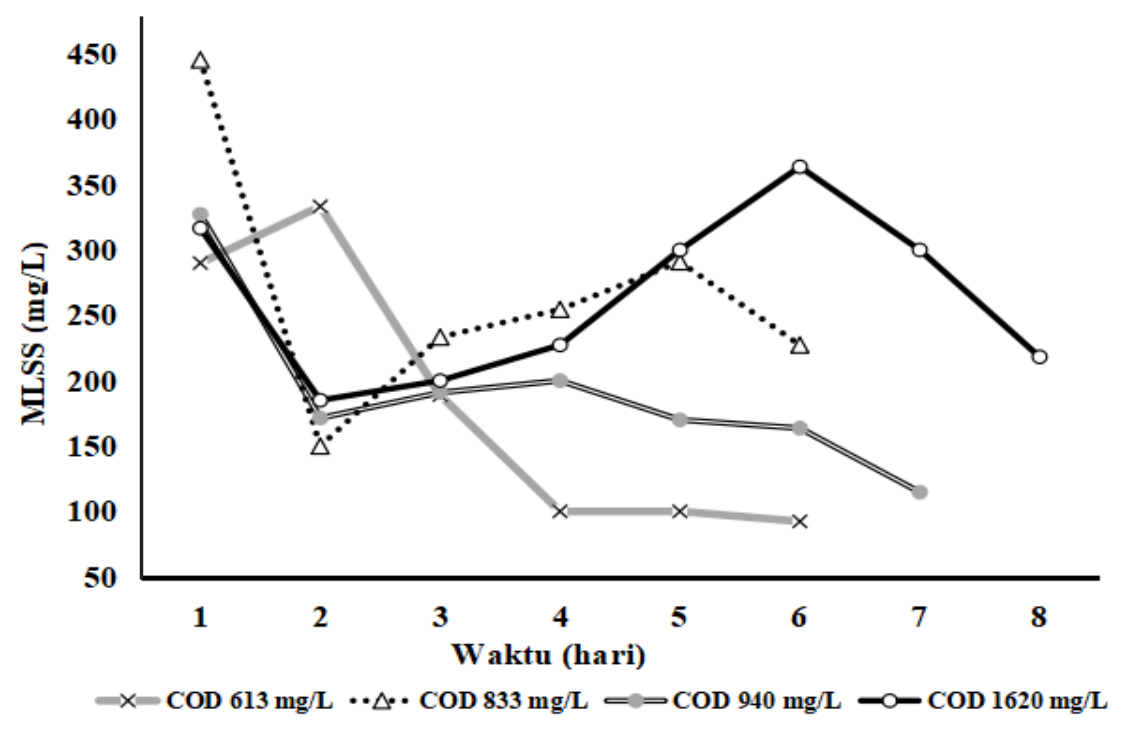

Gambar 3. Konsentrasi MLSS pada Reaktor MFC 


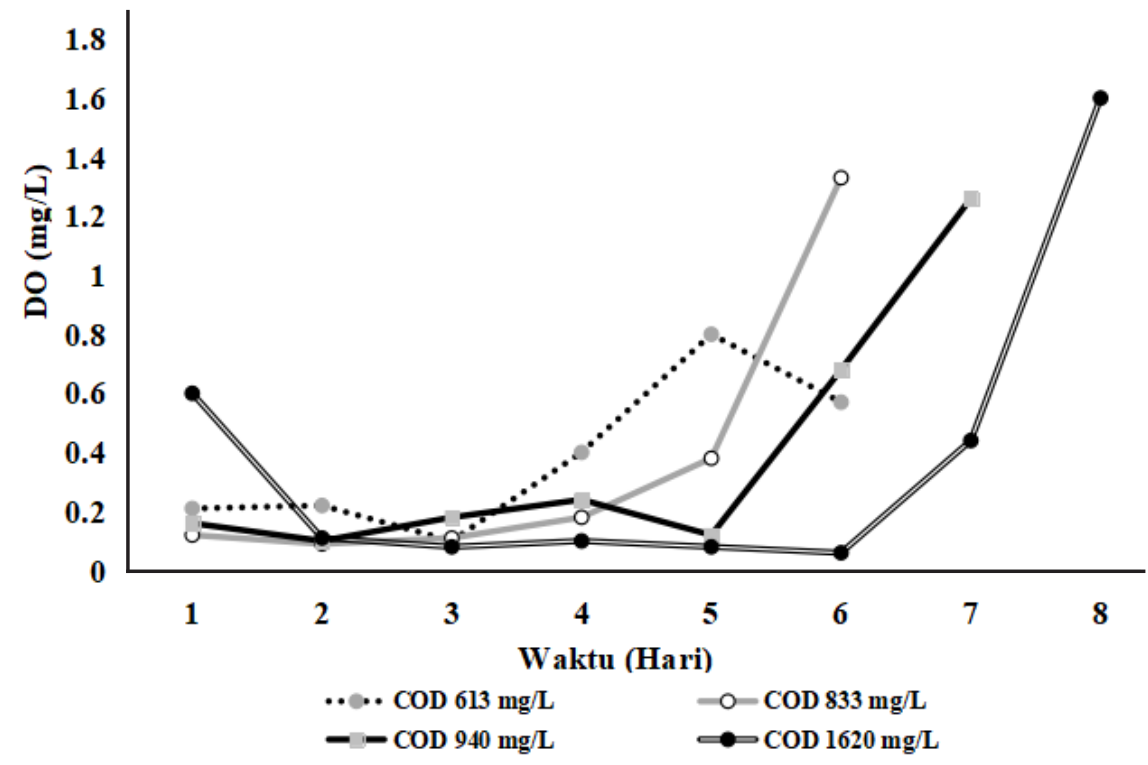

Gambar 4. Konsentrasi DO dalam Reaktor MFC

air limbah terbesar, yaitu $1620 \mathrm{mg} / \mathrm{L}$. Pada 2 hari pertama sejak air limbah dikontakkan dengan mikroba, konsentrasi MLSS yang diuji menunjukkan penurunan pada semua reaktor. Hal ini dapat disebabkan oleh beberapa hal, yaitu walaupun sebelumnya sudah mengalami proses aklimatisasi, tetapi ketika dikontakkan dengan air limbah yang konsentrasi COD yang lebih tinggi, kejadian beban kejut (shock loading) tetap dapat terjadi dan berakibat menurunnya jumlah mikroba yang ada. Jumlah mikroba meningkat seiring dengan meningkatnya kemampuan beradaptasi dengan konsentrasi air limbah. Selain itu, dapat disebabkan oleh jenis mikroba yang ada dalam reaktor MFC berupa mikroba yang bersifat suspended growth dan attached growth. Kedua jenis mikroba ini berkontribusi dalam produksi listrik dalam reaktor. Ketika pengambilan contoh (sampling) dilakukan dalam reaktor MFC, kemungkinan besar mikroba yang tersampling adalah mikroba yang tersuspensi sementara attached microbe akan melekat pada karbon ataupun pompa sirkulator yang terdapat dalam reaktor. Selain karena berkurangnya substrat, penurunan pertumbuhan mikroba dalam reaktor dapat disebabkan oleh kondisi lingkungan seperti $\mathrm{pH}$ dan DO yang tidak mendukung pertumbuhan mikroba di dalam reaktor MFC.

Hasil penelitian menunjukkan bahwa nilai DO air limbah pada umumnya mengalami penurunan pada 3 hari pertama, tetapi setelahnya mengalami peningkatan. Hal ini dapat disebabkan oleh penggunan water circulator yang dapat menambah difusi oksigen kedalam reaktor. Gambar 4 menunjukkan bahwa pada reaktor MFC ada kecenderungan konsentrasi DO meningkat setelah hari ke-5 dan terjadi pada semua reaktor. Tanikkul dan Pisutpaisal (2015) menyebutkan bahwa penggunaan air cathode MFC dapat meningkatkan difusi oksigen pada chamber anoda dan kondisi ini dapat mengurangi kinerja mikroba anaerob yang ada dalam reaktor MFC. Kenaikan DO pada reaktor MFC dapat mempengaruhi pertumbuhan MLSS. Peningkatan konsentrasi oksigen terlarut dalam reaktor MFC memberikan efek yang tidak baik terhadap pertumbuhan mikroba dalam reaktor MFC. Faktor lingkungan sangat berkontribusi terhadap keefektifan suatu pengolahan, utamanya memberikan kondisi ideal bagi mikroba dalam mendegradasi air limbah. Lebih lanjut, Pham et al., (2004) menyebutkan bahwa proses pada MFC terjadi berdasarkan adanya gradien DO antara bagian anaerob dan aerob dari reaktor MFC. Reaksi pada anoda sangat sensitif terhadap adanya oksigen terlarut. Adanya oksigen terlarut dapat menghambat metabolisme mikroba anaerob.

Hasil percobaan menunjukkan bahwa secara umum kenaikan konsentrasi DO dalam reaktor mempengaruhi penyisihan COD menjadi lebih rendah. Ada kecenderungan kurang optimalnya proses degradasi substrat terkait dengan adanya kenaikan oksigen terlarut pada pengolahan hari ke 5. Pengolahan dengan MFC adalah pengolahan biologi secara anaerob sehingga 
adanya peningkatan difusi oksigen dalam reaktor dapat berpengaruh terhadap kinerja mikroba. Peningkatan difusi oksigen dapat disebabkan oleh semakin menurunnya suhu lingkungan yang akan mempengaruhi kondisi reaktor. Penurunan suhu lingkungan menyebabkan kelarutan oksigen dalam reaktor semakin besar dan berakibat naiknya nilai oksigen terlarut di dalam air limbah. Peningkatan nilai DO akan menghambat kinerja mikroba anaerob dalam mendegradasi zat pencemar dalam air limbah. Adanya oksigen terlarut dapat menghambat metabolisme mikroba anaerob (Pham et al., 2004). Hanya saja bila dilihat lebih lanjut, kondisi reaktor yang memiliki substrat dengan konsentrasi COD awal terbesar, yaitu $1620 \mathrm{mg} / \mathrm{L}$, cenderung lebih mampu mempertahankan konsentrasi DO $<0,5 \mathrm{mg} / \mathrm{L}$ sampai hari ke 7, lebih lama apabila dibandingkan dengan reaktor lain yang rata-rata pada hari ke 5, konsentrasi DO dalam reaktor mencapai $>0,5 \mathrm{mg} / \mathrm{L}$. Halinidisebabkanolehkarena tingginya substrat yang ada dibandingkan dengan reaktor lainnya. Botheju, Lie, dan Bakke (2010) menyebutkan bahwa oksigen dapat dihilangkan dengan cepat ketika memasuki suatu wilayah anaerobik apabila substrat dalam jumlah yang banyak tersedia disana. Hal itu terlihat jelas pada kondisi pada hari pertama di dalam reaktor MFC yang memiliki substrat dengan konsentrasi COD awal $1620 \mathrm{mg} / \mathrm{L}$ dimana nilai DO awal $1,75 \mathrm{mg} / \mathrm{L}$ menurun drastis pada hari berikutnya menjadi $0,6 \mathrm{mg} / \mathrm{L}$ dan terus menurun sampai nilai $0,1 \mathrm{mg} / \mathrm{L}$ pada hari berikutnya.

Nevin et al. (2009) menyebutkan bahwa pengaturan $\mathrm{pH}$ berpengaruh terhadap jumlah proton yang dihasilkan. Penurunan $\mathrm{pH}$ larutan dalam MFC menurunkan produksi energi yang dihasilkan. Oleh karena itu, kondisi $\mathrm{pH}$ dalam reaktor harus terus dipantau agar tidak menghambat listrik yang diinginkan. Air limbah pencucian pulp yang digunakan cenderung bersifat basa karena dipengaruhi oleh lindi hitam yang memiliki $\mathrm{pH}$ tinggi. Dalam MFC diharapkan aktivitas pengolahan dilakukan oleh mikroba electrogenic, yaitu mikroorganisme yang dapat mentransfer elektron ke elektroda. Lovley dan Nevin (2008) menyebutkan bahwa mikroba ini memiliki banyak kelebihan dalam MFC seperti terjadinya oksidasi yang sempurna dari substrat organik dengan adanya transfer elektron ke elektroda, serta adanya kestabilan konservasi energi untuk pemeliharaan dan pertumbuhan dari transfer elektron ke anoda. Keberadaan mikroba metanogen dalam reaktor MFC dihindari karena elektron-elektron yang dihasilkan dari proses degradasi substrat akan digunakan untuk menghasilkan gas methan sehingga listrik yang diharapkan dari MFC tidak bisa terbentuk. Salah satu upaya agar mikroba metanogen tidak terbentuk selama proses pengolahan dengan MFC dapat dilakukan dengan cara mengatur $\mathrm{pH}$ di dalam reaktor MFC agar selalu di atas 8 dengan menggunakan $\mathrm{NaHCO}_{3}$ yang berfungsi sebagai buffer. Penurunan $\mathrm{pH}$ terbesar cenderung terjadi pada 4 hari pertama seiring dengan penyisihan COD air limbah di dalam reaktor yang juga terjadi paling signifikan di 4 hari pertama. Proses buffering yang dilakukan dengan penambahan $\mathrm{NaHCO}_{3}$ cukup berhasil dalam mempertahankan nilai $\mathrm{pH}$. Gambar 5 memperlihatkan bahwa setelah dilakukan intervensi $\mathrm{pH}$, penurunan $\mathrm{pH}$ tidak terjadi lagi walaupun proses penyisihan COD dalam air limbah tetap terjadi. Sebelum dilakukan proses buffering, penurunan $\mathrm{pH}$ dapat dijadikan indikator terjadinya proses pengolahan yang menghasilkan $\mathrm{CO}_{2}$, tetapi setelah dilakukan proses buffering, naik turunnya nilai $\mathrm{pH}$ dalam reaktor tidak dapat mencerminkan proses tersebut.

Gambar 6 memperlihatkan tegangan listrik yang terjadi dalam reaktor MFC cenderung mengalami penurunan seiring dengan semakin lamanya pengamatan. Reaktor dengan konsentrasi COD awal $613 \mathrm{mg} / \mathrm{L}, 833 \mathrm{mg} / \mathrm{L}$, dan 940 $\mathrm{mg} / \mathrm{L}$ menunjukkan penurunan nilai tegangan/ voltase sampai dengan angka dibawah voltase kontrol pada hari ke 5. Hanya reaktor dengan konsentrasi COD awal $1620 \mathrm{mg} / \mathrm{L}$ yang nilai voltasenya mampu bertahan sampai hari ke 7 . Penurunan voltase dalam reaktor MFC dapat disebabkan oleh kurangnya gradien DO diantara katoda dan anoda atau dengan kata lain terjadi difusi oksigen yang menjadi penyebab penurunan voltase sel yang terjadi dalam reaktor MFC. Proses dalam MFC terjadi dengan berdasarkan adanya gradien DO antara bagian anaerob dan aerob dari reaktor MFC. Reaksi pada anoda sangat sensitif terhadap adanya oksigen terlarut (Pham et al., 2004). Adanya difusi oksigen sangat merugikan kinerja MFC. Peningkatan DO dapat mengganggu proses anaerob reaktor MFC yang pada umumnya terjadi pada konsentrasi DO $>0,5 \mathrm{mg} / \mathrm{L}$ dan rata-rata pada hari ke-6. Adanya difusi oksigen dapat menghambat metabolisme mikroba anaerob sehingga adanya oksigen terlarut dapat menyebabkan terjadinya 


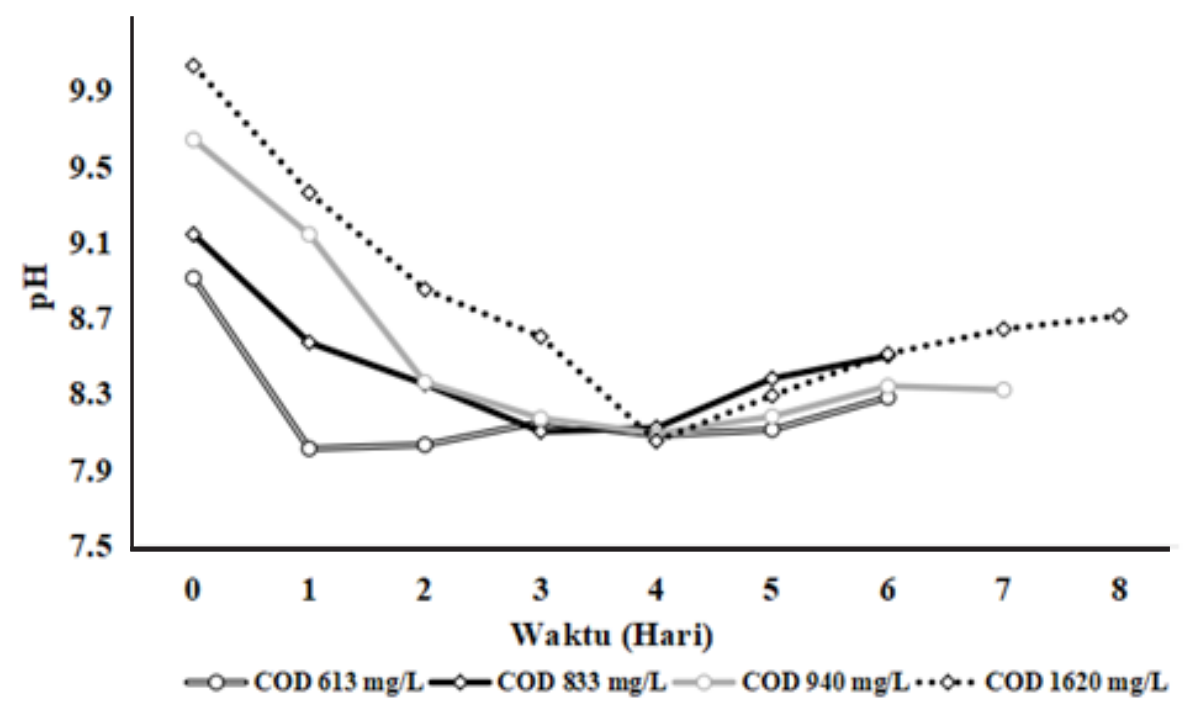

Gambar 5. pH MFC dalam Reaktor MFC

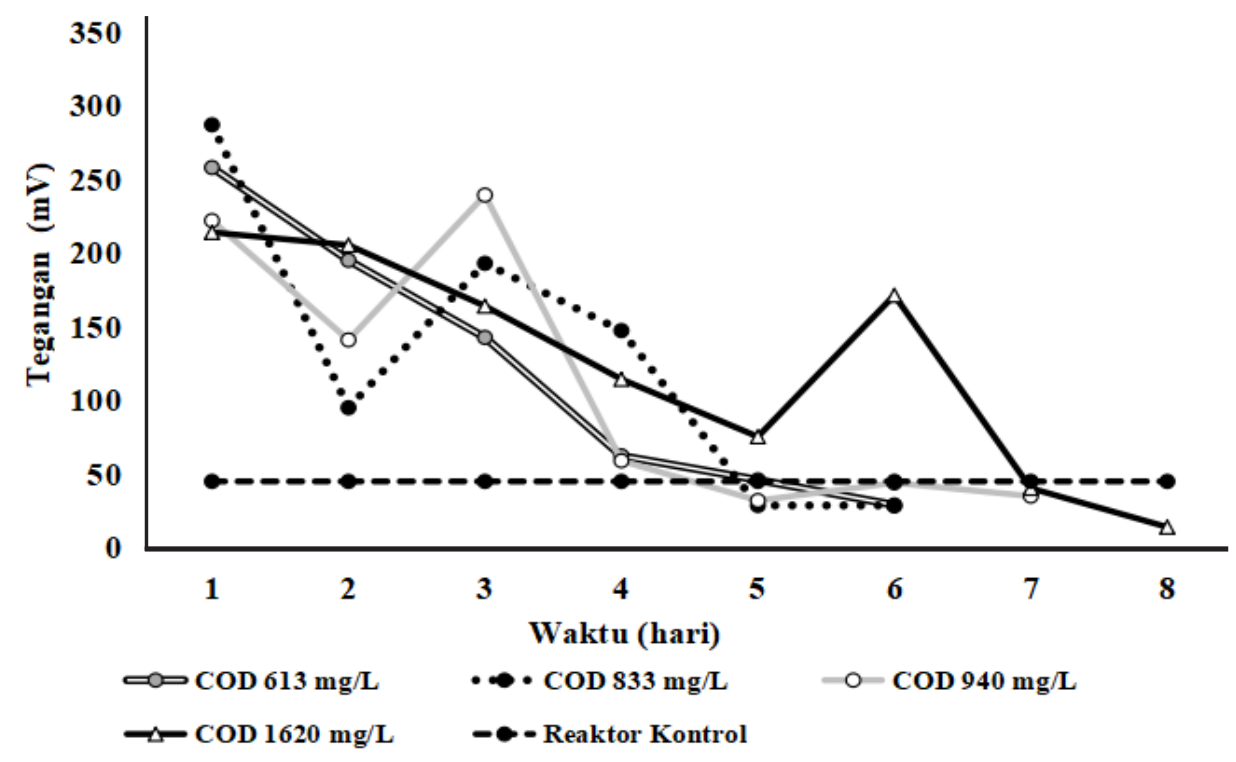

Gambar 6. Tegangan Listrik yang dihasilkan Reaktor MFC

persaingan dengan anoda sebagai penerima elektron dalam menggunakan elektron yang dihasilkan dalam proses metabolisme dalam ML-MFC. Penyebab penurunan voltase lainnya adalah keberadaan substrat. Terdapat hubungan yang searah antara voltase dan konsentrasi COD. Penurunan konsentrasi COD diikuti dengan penurunan voltase dalam reaktor MFC. Hanya saja dalam penelitian ini diduga substrat yang ada dalam reaktor MFC belum habis mengingat nilainya yang masih cukup besar bervariasi sekitar $500 \mathrm{mg} / \mathrm{L}$ sampai $900 \mathrm{mg} / \mathrm{L}$. Berhentinya proses degradasi COD dapat disebabkan oleh beberapa hal, diantaranya adalah kompleksitas substrat dan juga kondisi pengolahan yang kurang mendukung terjadinya proses degradasi oleh mikroba anaerob. Penurunan voltase dalam reaktor MFC secara otomatis akan menimbulkan efek terhadap arus yang ada mengingat adanya hubungan yang erat antara tegangan dan arus listrik. Secara umum grafik akumulasi arus cenderung semakin melandai seiring dengan terjadinya peningkatan nilai DO. Tegangan adalah beda potensial diantara dua titik dalam suatu rangkaian listrik yang memberikan tekanan ke arus listrik untuk mengalir. Arus listrik dalam 
reaktor dapat dialirkan apabila tegangan listrik yang tersedia memadai. Oleh karena itu, terdapat hubungan yang erat antara tegangan dan arus.

Gambar 7 menunjukkan terlihat bahwa seiring dengan penurunan tegangan listrik dalam reaktor maka grafik akumulasi kenaikan arus listrik akan melandai. Substrat air limbah dioksidasi oleh mikroba dan menghasilkan elektron dan proton pada anoda. Elektron kemudian dipindahkan melalui external circuit, sementara proton menyebar melalui larutan menuju katoda. Elektron berkombinasi dengan proton dan oksigen membentuk air (Cheng et al., 2006).

Penurunan konsentrasi COD berarti berkurangnya substrat organik yang dapat didegradasi dan mengalami biokonversi menjadi arus listrik. Kondisi stagnannya arus listrik tidak selalu menandakan bahwa substrat yang ada sudah habis tetapi dapat disebabkan oleh kondisi substrat tersisa yang didominasi oleh senyawa organik komplek yang sulit didegradasi oleh mikroba MFC. Chen et al. (2016) menyebutkan bahwa lindi hitam mengandung banyak lignin yang terlepas dari bahan baku pada proses pemasakan, serat, dan bahan organik lain yang mengandung konsentrasi COD, BOD yang tinggi, dan pencemar warna. Selain itu, tidak optimalnya proses degradasi substrat COD dapat juga disebabkan adanya difusi oksigen ke dalam reaktor MFC.

Ringkasan model kinetika first order yang digunakan untuk memprediksi penyisihan COD persatuan waktu (hari) dapat dilihat pada Tabel 1 dengan penyebaran titik dapat dilihat pada Gambar 8. Secara umum, terlihat bahwa peningkatan konsentrasi air limbah dari 613, 833, dan 940 mg/L meningkatkan nilai konstanta laju

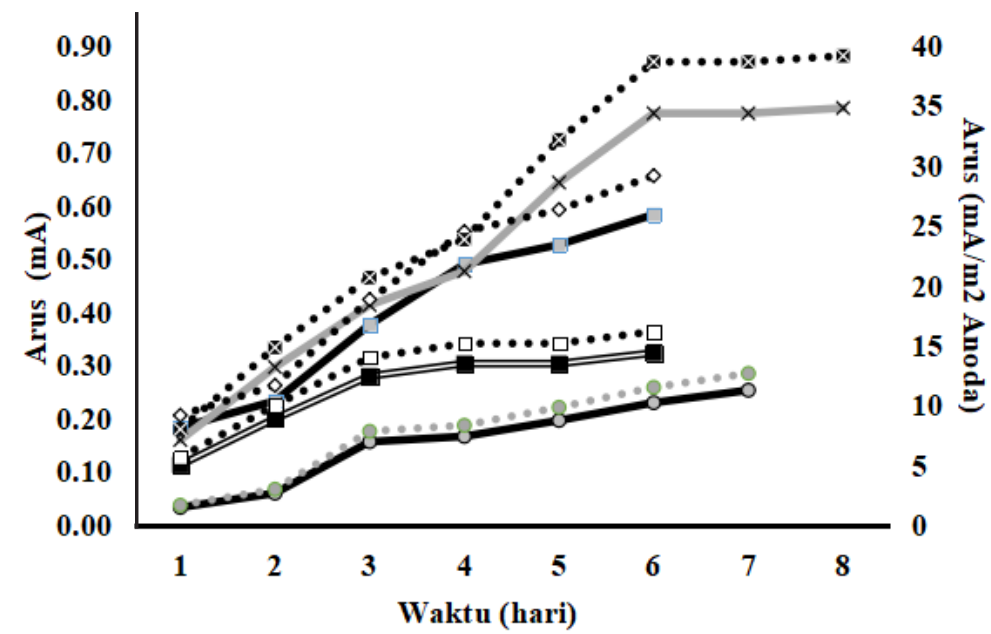

$=$ •COD $613 \mathrm{mg} / \mathrm{L} \longrightarrow$ COD $833 \mathrm{mg} / \mathrm{L} \longrightarrow$ COD $940 \mathrm{mg} / \mathrm{L} \longrightarrow$ COD $1620 \mathrm{mg} / \mathrm{L}$

$\bullet \bullet \cdot$ COD $613 \mathrm{mg} / \mathrm{L} \cdot \bowtie \cdot$ COD $833 \mathrm{mg} / \mathrm{L} \cdot \cdots \cdot$ COD $940 \mathrm{mg} / \mathrm{L} \cdot \cdots \bullet$ COD $1620 \mathrm{mg} / \mathrm{L}$

Gambar 7. Akumulasi Kenaikan Arus pada Reaktor MFC

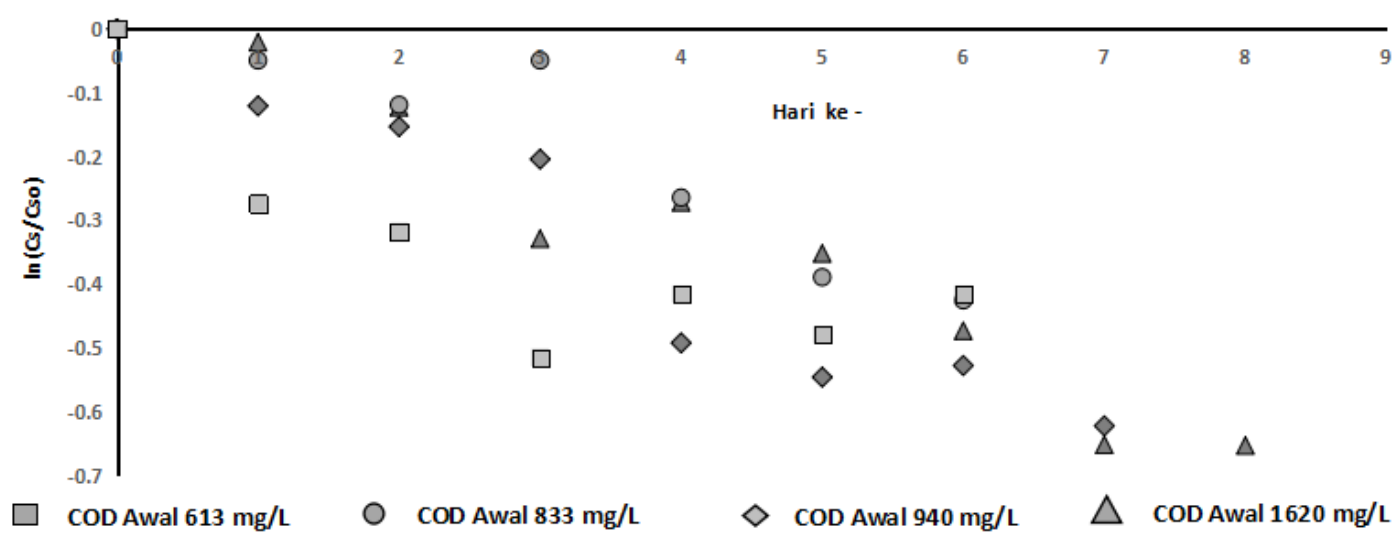

Gambar 8. Penyebaran Titik Model First Order Penyisihan COD 
Tabel 1. Nilai K dan $\mathrm{R}^{2}$ Model First Order

\begin{tabular}{lcccc}
\hline & \multicolumn{4}{c}{ Konsentrasi COD awal (mg/L) } \\
\cline { 2 - 5 } & 613 & 833 & 940 & 1620 \\
\hline $\mathrm{K}$, hari $^{-1}$ & 0,0626 & 0,0749 & 0,0934 & 0,087 \\
$\mathrm{R}^{2}$ & 0,6058 & 0,8703 & 0,9252 & 0,952 \\
\hline
\end{tabular}

Tabel 2. Korelasi antara COD dan Tegangan Listrik

\begin{tabular}{lcccc}
\hline $\begin{array}{l}\text { Konsentrasi Awal } \\
\text { COD }(\mathrm{mg} / \mathrm{L})\end{array}$ & 613 & 833 & 940 & 1620 \\
\hline Persamaan & $\mathrm{y}=2,5686 \mathrm{x}-950,25$ & $\mathrm{y}=0,6163 \mathrm{x}-276,53$ & $\mathrm{y}=0,5658 \mathrm{x}-256,46$ & $\mathrm{y}=0,3288 \mathrm{x}-291,27$ \\
$\mathrm{R}^{2}$ & 0,96 & 0,3 & 0,64 & 0,93 \\
\hline
\end{tabular}

reaksi (K). Peningkatan konstanta laju reaksi dapat menandakan laju reaksi yang didefinisikan sebagai perubahan konsentrasi reaktan persatuan waktu semakin besar. Selain itu, perubahan konsentrasi laju reaksi dapat dipengaruhi oleh konsentrasi air limbah yang ada. Nilai K yang didapat dari perhitungan serta nilai $\mathrm{t}$ (hari) yang sudah ditentukan dimasukkan dalam persamaan 1 untuk mendapatkan prediksi konsentrasi COD pada hari ke t. Dari Tabel 1 juga terlihat bahwa model kinetika first order untuk reaktor $1(613 \mathrm{mg} / \mathrm{L})$ dan $2(833 \mathrm{mg} / \mathrm{L})$ kurang sesuai dalam memprediksi degradasi air limbah pencucian karena nilai $\mathrm{R}^{2}$ yang rendah sementara kondisi terbaik yang dapat dijelaskan dengan model first order dalam penelitian ini ditunjukkan dengan nilai $\mathrm{R}^{2}$ terbesar terjadi pada reaktor $4(1620 \mathrm{mg} / \mathrm{L})$. Hubungan antara penurunan COD dengan tegangan listrik yang terjadi dalam tiap reaktor penelitian ini dapat dilihat pada Tabel 2.

Persamaan-persamaan ini didapatkan berdasarkan nilai COD dan tegangan listrik yang terjadi pada masing-masing reaktor. Persamaan ini menggambarkan pengaruh yang diberikan variabel COD $(\mathrm{x})$ terhadap voltase $(\mathrm{y})$. Reaktor 1 $(613 \mathrm{mg} / \mathrm{L})$ dan reaktor $4(1620 \mathrm{mg} / \mathrm{L})$ memiliki nilai $\mathrm{R}^{2}$ yang lebih besar dibandingkan reaktor lain, yaitu sebesar 0,96 dan 0,93. Angka ini menyatakan bahwa konsentrasi COD berpengaruh terhadap nilai voltase sebesar $96 \%$ dan $93 \%$, sedangkan sisanya dipengaruhi oleh variabel yang lain. Dalam penelitian ini, variabel itu dapat berupa konsentrasi DO ataupun yang lain.

\section{Kesimpulan}

Penggunaan Membraneless Air Cathode MFC dalam penelitian ini mampu menyisihkan COD air limbah pencucian dengan variasi konsentrasi COD awal berkisar 34\% sampai dengan 48\%. Voltase listrik tertinggi yang terjadi pada reaktor MFC dengan COD awal 613, 833, 940, dan $1620 \mathrm{mg} / \mathrm{L}$ berturut-turut adalah 258, 287, 222, dan $214 \mathrm{mV}$ dengan akumulasi arus listrik adalah $0,32 \mathrm{~mA}$ atau $16,17 \mathrm{~mA} / \mathrm{m}^{2} ; 0,58 \mathrm{~mA}$ atau $29,17 \mathrm{~mA} / \mathrm{m}^{2}$; $0,25 \mathrm{~mA}$ atau $12,67 \mathrm{~mA} / \mathrm{m}^{2}$, dan $0,78 \mathrm{~mA}$ atau $39,17 \mathrm{~mA} / \mathrm{m}^{2}$. Hasil ini membuktikan bahwa peningkatan konsentrasi COD awal air limbah pencucian yang diolah dengan MFC akan meningkatkan arus listrik dalam reaktor.

\section{Ucapan Terima Kasih}

Penulis mengucapkan terimakasih kepada Balai Besar Pulp dan Kertas dan Program Magister Teknik Lingkungan Institut Teknologi Bandung sehingga penelitian ini dapat terlaksana dengan baik.

\section{Daftar Pustaka}

Bond, D. R., Holmes, D. E., Tender, L. M. and Lovley, D. R. (2002) 'Electrode-reducing microorganisms that harvest energy from marine sediments', Science, 295(5554), pp. 483-485. doi: 10.1126/science.1066771.

Botheju, D., Lie, B. and Bakke, R. (2010) 'Oxygen effects in anaerobic digestion - II', Modeling, Identification and Control, 31(2), pp. 55-65. doi: 10.4173/mic.2010.2.2. 
Chen, T., Li, Y., Lei, L., Hong, M., Sun, Q. and Hou, Y. (2016) 'The influence of stock consistency on the pollution load in washing process', BioResources, 11(1), pp. 22142223. doi: 10.15376/biores.11.1.2214-2223.

Cheng, S., Liu, H. and Logan, B. E. (2006) 'Power densities using different cathode catalysts (Pt and CoTMPP) and polymer binders (Nafion and PTFE) in single chamber microbial fuel cells', Environmental Science and Technology, 40(1), pp. 364-369. doi: 10.1021/es0512071.

Doma, H. S. and Abou-Elela, S. I. (2003) 'Treatment of black liquor derived from nonwoody feedstocks', Transaction on Ecology and The Environment, 63, pp. 453-462.

Franks, A. E. and Nevin, K. P. (2010) 'Microbial fuel cells, a current review', Energies, 3(5), pp. 899-919. doi: 10.3390/en3050899.

Kim, S., Chae, K. J., Choi, M. J. and Verstraete, W. (2011) 'Microbial fuel cells: Recent advances, bacterial communities and application beyond electricity generation', Environmental Engineering Research, 13(2), pp. 51-65. doi: 10.4491/eer.2008.13.2.051.

Logan, B. E. (2009) 'Exoelectrogenic bacteria that power microbial fuel cells', Nature Reviews Microbiology, 7(5), pp. 375-381. doi: $10.1038 /$ nrmicro2113.

Lovley, D. R. and Nevin, K. P. (2008) 'Electricity Production with Electricigens', in Bioenergy. American Society of Microbiology, pp. 295306. doi: 10.1128/9781555815547.ch23.

Mahendra, B. G. and Mahavarkar, S. (2013) 'Treatment of wastewater and electricity generation using microbial fuel cell technology', International Journal of Research in Engineering and Technology, pp. 2321-7308.

Nevin, K. P., Kim, B.-C., Glaven, R. H., Johnson, J. P., Woodard, T. L., Methé, B. A., DiDonato, R. J., Covalla, S. F., Franks, A. E., Liu, A. and Lovley, D. R. (2009) 'Anode Biofilm Transcriptomics Reveals Outer Surface Components Essential for High Density Current Production in Geobacter sulfurreducens Fuel Cells', PLOS ONE. Edited by M. G. Marinus, 4(5), p. e5628. doi: 10.1371/journal.pone.0005628.
Parkash, A., Aziz, S., Abro, M., Kousar, A., Soomro, S. A. and Jatoi, A. S. (2015) 'Impact of agarose concentrations on electricity generation using hostel sludge based duel chambered microbial fuel cell', Sci.Int. (Lahore), 27(2), pp. 1057-1061.

Pham, T. H., Jang, J. K., Chang, I. S. and Kim, B. H. (2004) 'Improvement of cathode reaction of a mediatorless microbial fuel cell', Journal of Microbiology and Biotechnology, 14(2), pp. 324-329.

Pramono, K. J., Wardana, K. A., Asthary, P. B. and . S. (2015) 'Biokonversi bahan organik pada pengolahan air limbah industri pulp dan kertas menjadi energi listrik (ML-MFC)', JURNAL SELULOSA, 5(1), pp. 39-46. doi: 10.25269/jsel.v5i01.77.

Shukla, S. K., Kumar, V., Kim, T. and Bansal, M. C. (2013) 'Membrane filtration of chlorination and extraction stage bleach plant effluent in Indian paper Industry', Clean Technologies and Environmental Policy, 15(2), pp. 235243. doi: 10.1007/s10098-012-0501-6.

Tanikkul, P. and Pisutpaisal, N. (2015) 'Performance of a membrane-less aircathode single chamber microbial fuel cell in electricity generation from distillery wastewater', in Energy Procedia. Elsevier Ltd, pp. 646-650. doi: 10.1016/j. egypro.2015.11.548.

Thung, W. E., Ong, S. A., Ho, L. N., Wong, Y. S., Ridwan, F., Oon, Y. L., Oon, Y. S. and Lehl, H. K. (2015) 'A highly efficient single chambered up-flow membrane-less microbial fuel cell for treatment of azo dye Acid Orange 7-containing wastewater', Bioresource Technology. Elsevier Ltd, 197, pp. 284-288. doi: 10.1016/j.biortech.2015.08.078.

Zhuwei, D., Qinghai, L., Meng, T., Shaohua, L. and Haoran, L. (2008) 'Electricity generation using membrane-less microbial fuel cell during wastewater treatment', Chinese Journal of Chemical Engineering, 16(5), pp. 772-777. doi: 10.1016/S10049541(08)60154-8. 